ppi $201502 Z U 4645$

Esta publicación cientifica en formato digital es continuidad de la revista impresa ISSN-Versión Impresa 0798-1406 / ISSN-Versión on line 2542-3185Depósito legal pp

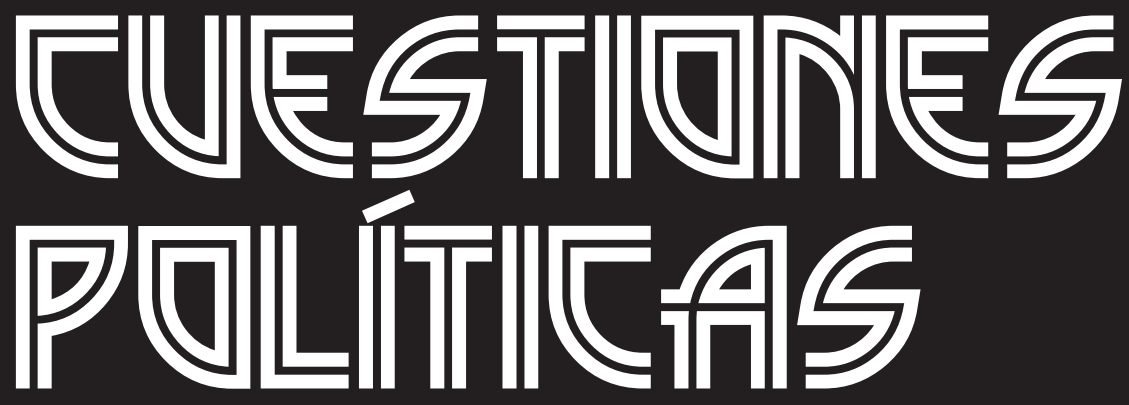

Instituto de Estudios Políticos y Derecho Público "Dr. Humberto J. La Roche' de la Facultad de Ciencias Jurídicas y Políticas de la Universidad del Zulia Maracaibo, Venezuela
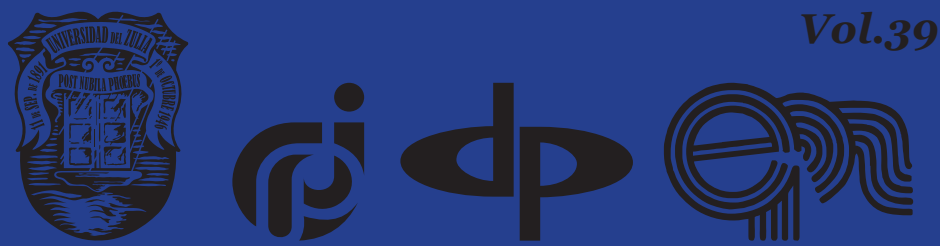


\title{
Chaos Theory: The Case of the COVID-19 Pandemic in Wuhan, China from the perspective of international relations
}

\author{
DOI: https://doi.org/10.46398/cuestpol.3968.23
}

\begin{abstract}
Natalia Vladimirovna Kovalevskaia *
Iuliia Alexandrovna Fedoritenko ** William Leahy $* * *$
\end{abstract}

\begin{abstract}
The objective of the article was to reveal the international imbalances caused by the COVID-19 pandemic through the coordinates of chaos theory. Methodologically it is a critical essay based on documentary observation. To understand the current state of world politics and the balance of power in international relations, it is appropriate to use chaos theory. At the beginning of the article, the origins of chaos theory are an interdisciplinary study, and its basic concepts are introduced. The value of using chaos theory and its great potential for analysis and applications in the study of international relations is shown in the example of the 2019-2020 events in Wuhan is the capital of Hubei Province in the People's Republic of China (PRC). associated with the onset of a COVID-19 viral infection that has spread around the world. At the end of the article, conclusions are drawn and the strengths and weaknesses of the use of chaos theory in dialectical relation to international relations are revealed, both as a field of study and at the
\end{abstract} same time as geopolitical reality.

Keywords: chaos theory; social change of complex systems; COVID-19 pandemic, criticality; self-organized criticality.

Saint Petersburg State University, Saint Petersburg, Russian Federation. ORCID ID: https://orcid. org/oooo-0003-0864-0937. Email: nk@bossner.de

** Saint Petersburg State University, Saint Petersburg, Russian Federation. ORCID ID: https://orcid. org/o000-0002-2197-3093. Email: st012685@student.spbu.ru

*** MGIMO (Moscow State Institute of International Relations), Moscow, Russian Federation. ORCID ID: https:// orcid.org/0000-0002-7743-3432. Email: w.leahy@my.mgiomo.ru 
Natalia Vladimirovna Kovalevskaia, Iuliia Alexandrovna Fedoritenko y William Leahy

370

Chaos Theory: The Case of the COVID-19 Pandemic in Wuhan, China from the perspective of international relations

\section{Teoría del Caos: el Caso de la Pandemia COVID-19 En Wuhan, China desde la perspectiva de las relaciones internacionales}

\section{Resumen}

El objetivo del artículo fue revelar los desequilibrios internacionales ocasionados por la pandemia de COVID-19 mediante las coordenadas de la teoría del caos. Metodológicamente se trata de un ensayo crítico con base a la observación documental. Para comprender el estado actual de la política mundial y el equilibrio de poder en las relaciones internacionales, es apropiado utilizar la teoría del caos. Al inicio del artículo se consideran los orígenes de la teoría del caos como un estudio interdisciplinario y se introducen sus conceptos básicos. El valor de utilizar la teoría del caos y su gran potencial de análisis y aplicaciones en el estudio de las relaciones internacionales se muestra en el ejemplo de los eventos de 2019-2020 en Wuhan es la capital de la provincia de Hubei en la República Popular China (PRC). asociado a la aparición de una infección viral COVID-19 que se ha extendido por todo el mundo. Al final del artículo, se hacen conclusiones y se revelan las fortalezas y debilidades del uso de la teoría del caos en relación dialéctica con las relaciones internacionales, tanto como campo de estudio y al mismo tiempo como realidad geopolítica.

Palabras clave: teoría del caos; cambio social de sistemas complejos; pandemia de COVID-19, criticidad; criticidad autoorganizada.

\section{Introduction}

In modern scientific theory and experience, interdisciplinary knowledge, methods, and research tools are gaining popularity. Researchers apply the concept of inter-disciplinarity in the narrow and broad meaning. In the narrow meaning, interdisciplinary studies are those, which integrate knowledge created within two different disciplines. In a broad sense, interdisciplinary studies include also multi-disciplinary studies - that is, those seeking to integrate knowledge developed within three or more disciplines. International studies as an interdisciplinary field of knowledge seeks integrating achievements of many disciplines. In this article the relevance of use of chaos theory and its interdisciplinary methods in International Relations are covered. 


\section{Methods}

In this study chaos theory and self-organized criticality force were applied to the case of COVID-19. Periodic pandemics in China, including the coronavirus pandemic were figured out under the scope of chaos and epidemic theory. Critical-point in epidemics of COVID-19 in China. Stagnation and further recovery according to chaos theory were presented.

\section{Origins of chaos theory}

A breakthrough was achieved in 1977, dissipative structures were discovered by Ilya Prigogine. These structures are systems which have no condition of thermodynamic equilibrium, and get acquire the quality of complex, often chaotic structures. Their behavior contradicts the principles of classical mechanics and comply with the principles of the theory of relativity. The concept of nonequilibrium thermodynamics, as well as the idea of the concurrent coexistence of order and disorder (entropy in the language of thermodynamics) were introduced into the study (Prigogine and Stengers, 1986). Innovation of I. Prigogine's theory lies in recognizing the positive role of chaos in physics. The growth of disorder (entropy) in physical systems leads to the destruction of systems, nevertheless it gives prospects for their transformation with qualitatively new system requirements (Prigogine, 1977).

A factor (attractor) determines the choice in the system and acts as a reference point to indicate the way for further change. Such a choice occurs during the bifurcation point by the system. The number of possible ways of developing the system at such a point can be huge and limited only by the number of factors (Prigogine, 1977).

\section{Chaos theory in research of International Relations}

Such complex systems as international relations are subject to the principle of self-organizing criticality and they evolve to a critical stage at which a minor event triggers a chain reaction that can affect many elements of the system. A stable structure and stability are inside the most visible disorder and non-linear processes. Chaos theory describes the statistical trends of a large number of interacting objects and factors, based on the nonlinear behavior of the system (Prigogine, 1977).

International relations are also an example of a chaotic system. One of the key concepts of chaos theory, such as self-organizing criticality (SOC) is an effective tool for scientific analysis. In the field of national strategy, the use of chaos theory is not only appropriate, but also most effective. Understanding the nature of chaos and adapting the model in political 
Natalia Vladimirovna Kovalevskaia, Iuliia Alexandrovna Fedoritenko y William Leahy

science can change the way we consider the interaction of actors - the interactive systems constantly bring themselves to a critical state through organization, as in nonlinear analysis - a small event can trigger a chain reaction that can lead to collapse (Shimada and Koyama, 2015).

Chaos theory examines the mechanism of unpredictable (random) phenomena in the so-called nonequilibrium systems, their evolution consists of alternating dynamic and chaotic stages. Chaos plays the most important role for such systems, since it is at the stage of chaos (more precisely, at the exit from it) that new valuable information appears.

Within the dynamic stages, the system can be calculated, and a reliable prediction can be made for it. On the contrary, in the chaotic stage, getting to the point of bifurcation, the state of the system changes extremely rapidly in leaps and bounds. In fact, this is an algorithm that determines the behavior of an object at a bifurcation point, which is a certain subset of the phase space of system states.

Each possible state of the system is a point in its phase space (the space of possibilities of the system). And the trajectory of the system in this space shows the dynamics of the transitions of the system from one state to another. A transformation in the state of the system, initiated at the bifurcation point, can turn out to be unpredictable. In decision-making practice, the situation when it is necessary to make decisions at bifurcation points is called Radical Uncertainty (RU).

\section{Chaos theory and self-organized criticality force on the example of COVID-19}

The good example how dependent from changes occurred in one place is the COVID-19 pandemic. At the end of 2019, Wuhan became the location for the severe coronavirus that in several months spread to the entire world. By the most common version the virus originated in Wuhan's downtown seafood market.

World Health Organization (WHO) started tracing the growth of COVID-19 cases from the very beginning, organizing global data exchange between states. By the end of January 2020, 20 countries and territories had reported cases of COVID-19. The number grew rapidly to 202 by the end of March. Altogether, there are 3059642 cases of infection and 211028 deaths reported. COVID-19 has spread to all continents except Antarctica, and less than 30 countries, territories and areas have reported no COVID-19 cases (most of them are situated in the Pacific islands) (Committee for the Coordination of Statistical Activities, 2020). 


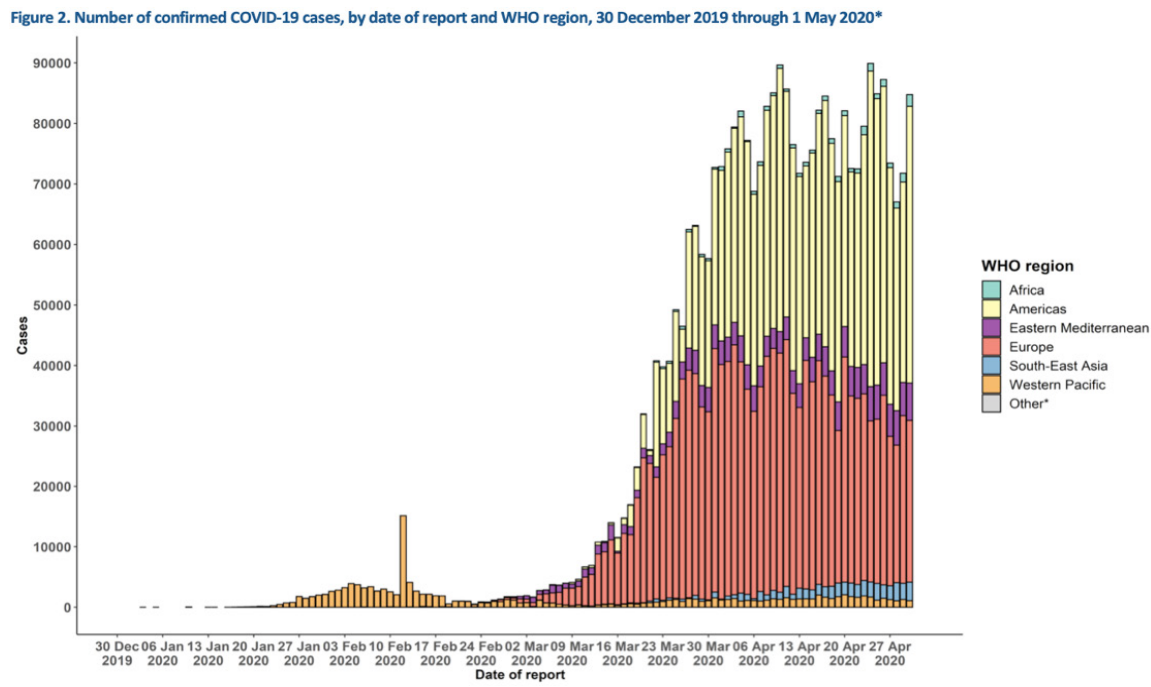

Figure 1: Number of confirmed COVID-19 cases, by date of report and WHO region, 30 December 2019 through 1 May 2020.

Source: World Health Organization (2020a).

For the first two months of 2020, China showed a sharp reduction of output, which can be explained by the celebrations of the Chinese New Year at the end of January 2020 as well as the beginning of the lockdown of Wuhan and other regions to contain the virus at the same time (Third World Network, 2020). It remains to be seen; how fast China will catch up the losses made during the first quarter of 2020.

On January 23, 2020, Wuhan went into strict lockdown in order to stop the spread of the virus. In early February, the outbreak in Wuhan hit its breaking point (Yuan et al., 2020).

The spread of the novel virus is not dictated by the geographical distance from Wuhan in China - as the outbreak in northern Italy shows. The routes of airplanes and cruise ships appear to influence the dissemination of the virus in the early phase. Entangled webs, not concentric circles, are a more appropriate representation of the propagation of the supply shocks in the case of COVID-19 (Baldwin and Weder Di Mauro, 2020). 


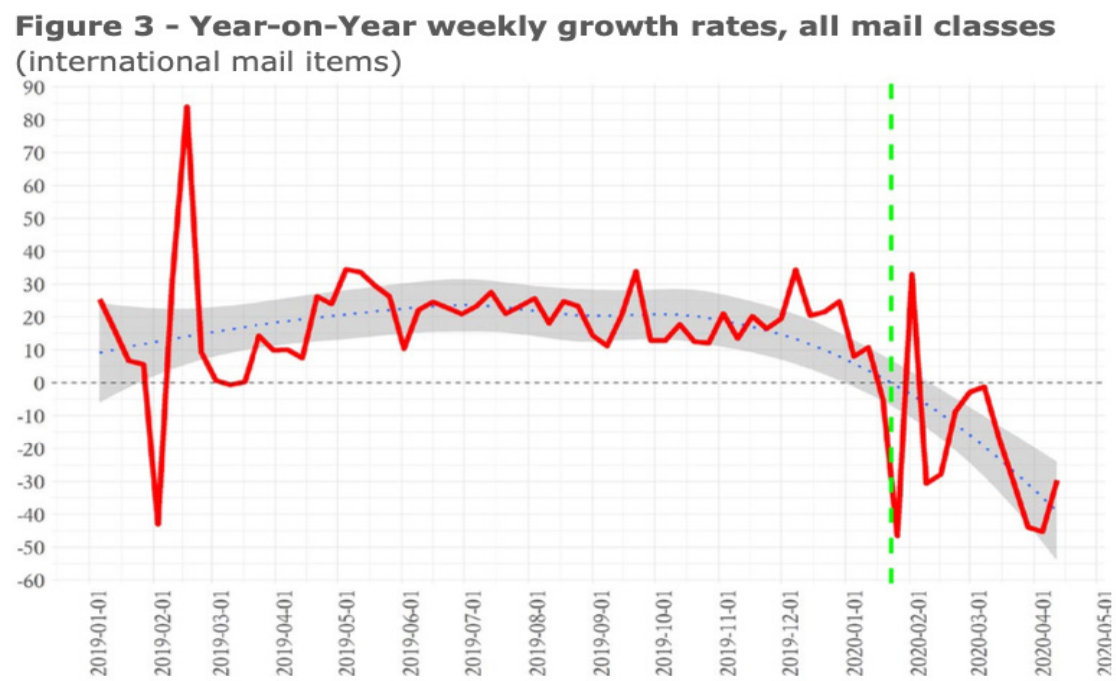

Figure 2: Year-on-year weekly growth rates, all mail classes (international mail items).

Source: Baldwin and Weder Di Mauro (2020).

The dotted line displays the tendency. The dashed vertical line indicates the lockdown of Wuhan international airport. The red line depicts annual growth rates. The spikes in 2019 correspond to seasonal holidays.

The epidemic, began in one of the Chinese provinces, in the short term has caused global disruption in social and economic systems. Under the worst-case scenario, it is estimated that because of COVID-19 by 1 March 2020, the total number of people confirmed with COVID-19 in China had reached 80174 and a total of 2915 people had died of the disease, in the world grand total of confirmed with COVID-19 - 7 169; 104 people died (World Health Organization, 2020b). 


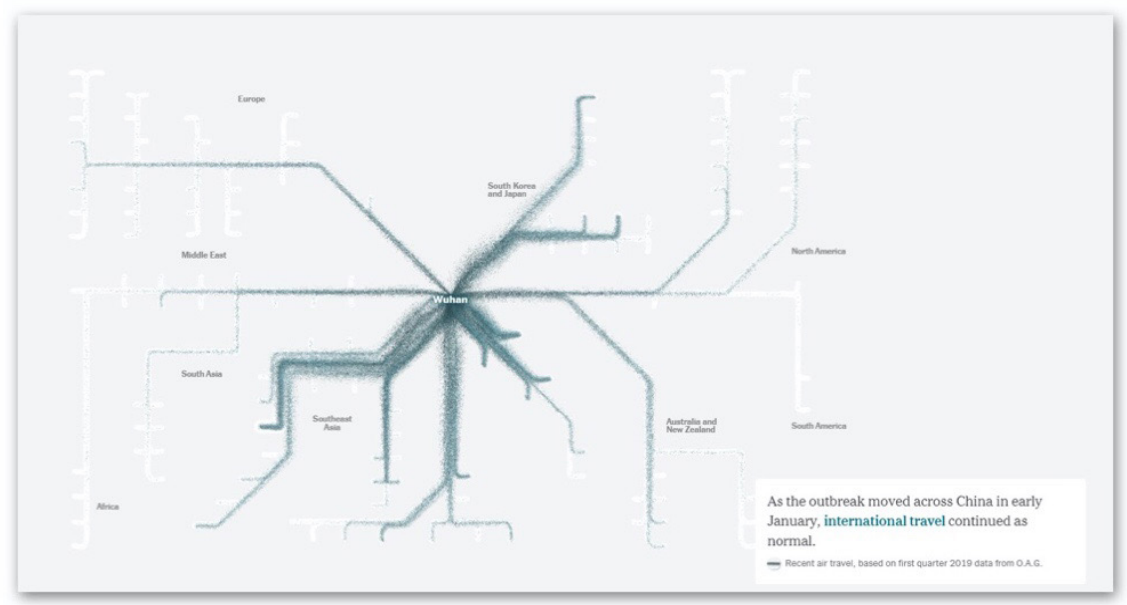

Figure 3: How the Virus Got Out (Wu et al., 2020)

Situation by Country, Territory \& Area

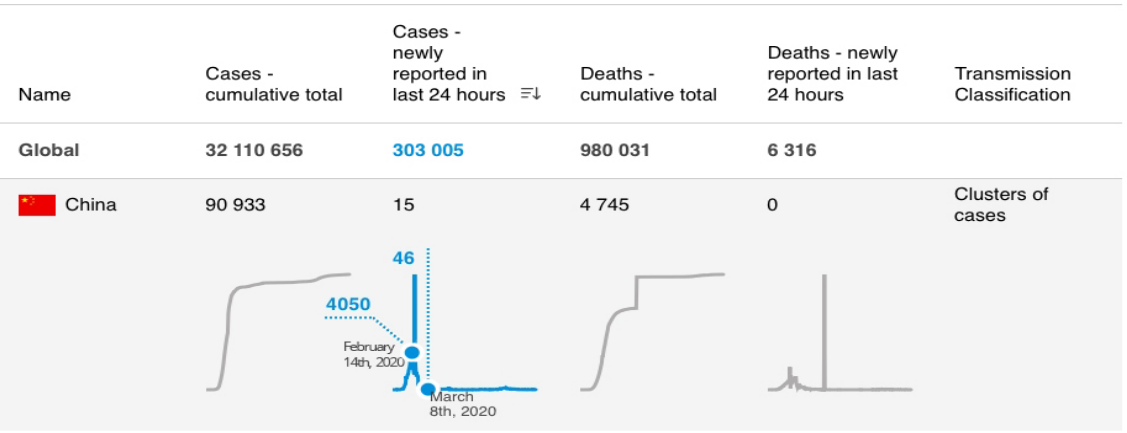

Figure 4: Situation by Country, Territory \& Area. Source: World Health Organisation (2020b).

Millions of people have faced extreme poverty. Sporting, religious, political, and cultural events were delayed or cancelled. It also affected education process because schools, universities, and colleges have been closed. It is obvious that the coronavirus pandemic started in Wuhan affected all social shears across scales from global to national and subnational levels.

The main actors, in the traditional sense, have a decisive influence on the course of events in international relations. Chaos theory and self- 
Natalia Vladimirovna Kovalevskaia, Iuliia Alexandrovna Fedoritenko y William Leahy 376

organized criticality force us to reconsider this statement. Both concepts show the disproportionate effects that small actors can provoke. On this basis, every actor, be it governments, organizations, or individuals in political critical systems, produces an active force that provokes a change in the original position and creates a critical state (Byeon, 2000). And the case with coronavirus in Wuhan illustrated that clearly.

\section{Chaos and epidemic theory. Periodic pandemics in China}

International relations are an aperiodic system. The number of people rises and falls almost regularly, epidemics begin and continue, contrary to human hopes, also in a certain order.

Nevertheless, epidemiologists are well aware that massive outbreaks of diseases appear, as a rule, with a certain cyclicality - regularly or irregularly, go on the offensive and retreat periodically.

The outbreak of the novel coronavirus (COVID-19) in Wuhan shows some interesting parallels to pandemics close to our days with similar symptoms, which also began in China. In February 1957, the world was shocked by the 1957-1958 influenza pandemic, also known as the Asian flu, the starting point of which was the Chinese province of Guizhou. It should be noted that those infected died from the disease within a few days. At first, the symptoms typical of the flu appeared: headache and muscle pain, cough, and fever. And then pneumonia, which arises as a complication, led to death (Viboud et al., 2016).

Later, scientists found out that the "Asian flu" was caused by a new subtype of the virus A (H2N2), originating from strains of avian and human influenza viruses.

During the development of the pandemic, namely from 1957 to 1958 , as a result of infection, according to WHO, 1.1 million people died - according to unconfirmed information (Viboud et al., 2016).

By 1957, the disease had stopped spreading, but a decade later, the virus mutated and returned, leading to a new pandemic that did not leave the world from 1968 to 1969. This disease was called the "Hong Kong flu" - its causative agent was, again, a previously unknown subtype of the A ( $\left.\mathrm{H}_{3} \mathrm{~N}_{2}\right)$ virus (Jester et al., 2020). It began in Hong Kong - while initially he only walked by sea, infecting the crews and passengers of ships. And since this is a large port city, it spread rapidly further. Air travel by an estimated 160 million persons during the pandemic facilitated rapid transmission worldwide (Grais et al., 2020).

Since their emergence, influenza $\mathrm{A}\left(\mathrm{H}_{3} \mathrm{~N}_{2}\right)$ viruses have caused substantial cumulative morbidity and mortality worldwide during seasonal 
influenza epidemics, greatly exceeding their impact in the first years of the pandemic beginning in 1968 (Grais et al., 2020).

"Asian" and "Hong Kong" flu disappeared together in 1969, but then they were not defeated by humans, as scientists believe, the viruses themselves died out. Infections caused by the virus have not returned for more than 30 years, so in 2002, no one expected to hear about the Severe acute respiratory syndrome (SARS) coronavirus, which later became the causative agent of a disease called severe acute respiratory syndrome. The first case of severe acute respiratory syndrome was reported in November 2002 in Guangdong, China. SARS was the first known major pandemic caused by a coronavirus. During the epidemic in 2003, 8096 cases with 774 deaths had occurred in over 30 countries among five continents (Cheng et al., 2007).

\section{Critical-point in epidemics of COVID-19 in China. Stagnation and further recovery according to chaos theory}

The radical turning point in the COVID-19 epidemic in China can be roughly designated March when Wuhan is at the epicenter of the spread of a new type of coronavirus. It is possible to identify several main reasons why this particular point was chosen and the prerequisites for the fact that the epidemic in the PRC will soon come to naught.

On the one hand, it is significant that by March the last of the 14 mobile hospitals for patients with COVID-19 had been closed. The last one was the Fangcang makeshift hospital converted from the Wuhan Sports Center, in Wuhan, Central China's Hubei Province. The hospital has shown excellent results: it has admitted that 1124 patients recovered, none of the doctors became infected (including 833 discharged and 291 transferred) (Wei, Keyue, 2020).

The need for mobile clinics has disappeared, since even in Wuhan, the incidence rate has dropped tenfold. If at the height of the epidemic, about 4000 cases of the disease were recorded daily in China, then on the worst days, February $14-4$ 050, then as of March 8 - only 46,17 of them in Wuhan. Thus, a downward trend in the incidence rate across the country was clearly demonstrated, and even in the very epicenter of the epidemic (WHO Coronavirus Disease (COVID-19) Dashboard, 2020) (World Health Organization (2020c).

On the other hand, economic activity in the PRC against the backdrop of the coronavirus pneumonia epidemic has been demonstrated. On March 13, the China Ministry of Industry and Information Technology claimed state-owned enterprises and large industrial companies had resumed work at about a 90 percent rate, while small- and medium-sized 
enterprises (SMEs) outside of Hubei Province had resumed work at a 60 percent rate. However, a half of 119 companies surveyed by AmCham China reported revenue declines of 10 percent or higher on March 25 (US. -China Economic and security review commission, 2020).

Official data released as of mid-March show a severe decline in output. Industrial output dropped 13.5 percent in January and February of 2020the largest contraction on record (US. -China Economic and security review commission, 2020). The manufacturing Purchasing Managers' Index (PMI) dropped to an historic low of 35.7 in February, lower than the 38.8 level recorded during the 2008 Financial Crisis. Though it rose to 52.0 in March, China's National Bureau of Statistics cautioned this expansionary figure "more reflects that more than half of the surveyed enterprises had returned to work and production," an improvement over last month, and "did not mean that China's economic operation had returned to normal", but still trends are relatively good.

The COVID-19 had the prospective to shut down the worldwide 'official statistics' industry as national statistical systems faced large disruptions in their business operations. Rather than shutting down - the national statistical system faced the challenges head on - and through innovation, resiliency and international cooperation were able to ensure the continued steady flow of official statistics to its citizens at a time when they needed it the most.

Modern scientific theory of decision making is based mainly on the classical paradigm of rationality. It searches for optimal solutions in the context of known results and their probabilities. However, this paradigm is powerless in the case of radical uncertainty.
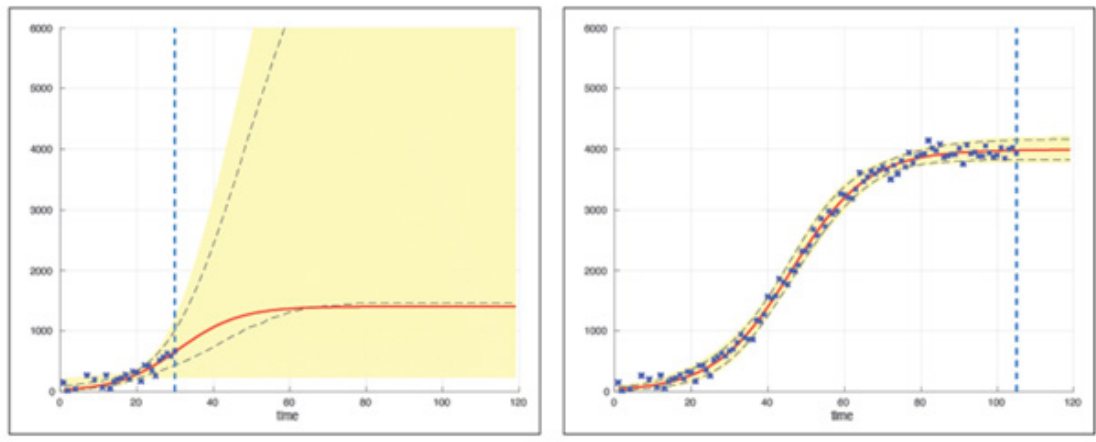

Figure 5: source: (Tuckett et al., 2020). 
Left picture. The blue dotted line at time 30 for a limited amount of available data on the situation (blue crosses) calculated the optimal statistical match; red line - process model; the cone of possibilities (colored yellow), due to certain clearly formulated assumptions, turns out to be huge.

Right picture. The same thing, but at the moment of time 105. The huge cone of possibilities has radically decreased, turning into a narrow strip.

Thus, decision makers cannot make the right decision, since such a decision simply does not exist at this point in time. Furthermore, all data are not available, their use to accurately understand what is happening and how the pandemic is developing is unreliable.

\section{What did you state chaos theory and what recommendations can be given to decision-makers based on Radical Uncertainty?}

In situations like the COVID-19 pandemic, guidance for decisionmakers is extremely limited. It is also necessary during the development of the situation not to fall into the area of the bifurcation point, when the decision-making paradigm should be changed.

The first provision is discussed in detail in Post-normal Pandemics: Why Covid-19 requires a New Approach to Science, where, using the example of the COVID-19 pandemic, the futility of attempts to make informed and accurate decisions from the standpoint of the rational paradigm of science is shown.

By March, China had a clear and well-functioning health emergency response system that has made the fight against the virus unprecedentedly effective. The fight against coronavirus allowed to test the effectiveness of the public administration reforms implemented by Xi Jinping. It embraced the entire society of China, starting from the lower levels of self-government, which made it possible to organize effective control over the situation.

When spring 2020 began the situation was getting more optimistic, because help started pouring in from all over the world. The epidemic mechanisms worked out on the example of China can be used in the future in the context of global instability. It became clear: helping Wuhan is helping the World. Thousands of medical workers and countless volunteers arrived from across the country. Japan donated truckloads of food and medicine (Gilead Sciences, 2020). For the seriously ill, American drug remdesivir offered new hope, given by Gilead Sciences, a pharmaceutical company, contributing antiviral expertise and resources to help patients and communities fighting COVID-19 (Biggeri et al., 2020). But unfraternally, remdesivir did not live up to expectations. In the spring of 2020, several clinical trials of remdesivir began in different countries (Norrie, 2020). One 
Natalia Vladimirovna Kovalevskaia, Iuliia Alexandrovna Fedoritenko y William Leahy 380

study, which began in China on evidence-based medicine standards, was interrupted early because, according to the authors, they could not recruit the required number of patients. This study, even incomplete, showed no significant therapeutic effect for remdesivir therapy, however, the smaller planned number of patients and early completion of the study did not provide confidence in the result (Wang et al., 2020).

The World Health Organization announced on February 5 a $\$ 675$ million response plan through April 2020 to further control the virus' spread and to protect states with weak health systems (Albert, 2020).

When the coronavirus has already spread all around Russia produced a vaccine for widespread use against the novel coronavirus. The Ministry of health of the Russian Federation on 11 August issued a registration certificate for a vaccine for the prevention of novel coronavirus infection COVID-19 developed by the National research centre of epidemiology and Microbiology named after academician N. F. Gamalei, Russian Ministry of Health (Logunov et al., 2020).

What happens if you get vaccinated against COVID-19 based on chaos theory? Robert May, one of the founders of chaos theory, was the first to realize that oscillations could be reproduced by a nonlinear model and became interested in what would happen if the system received a sudden impulse - a hindrance, such as mass vaccination. It would seem that the process should smoothly change in the desired direction. In fact, as May discovered, there would be some very tangible fluctuations. Even if the long-term trend is harshly canceled out, the path to new equilibrium will be interrupted by astounding upswings (Gleick, 1987).

\section{Conclusion}

All these examples demonstrate that the coronavirus pandemic revealed a high degree of connectivity of humanity, activated small segments of the audience and gave dynamism to the flows in the political system. Physical distancing has robbed us of the many opportunities that arise from inperson interactions, which are crucial during times of uncertainty.

Chaos theory brought new concepts like considered in sufficient detail self-organized criticality (Ermolina et al., 2020). They allow the researcher to develop new aspects of social and political science. It allows to understand that it is expedient to provide not so much a rigid order and stability as a soft, not catastrophic shift in the system. In other words, the concept of chaos theory can be used to improve the regulation of the system in international relations.

COVID-19 and the related economic turmoil has been a reminder that we cannot plan everything. Nonetheless, challenging times often depend on 
when we stop the story. For example, if a job falls through, we need to take the long view (Bondarenko et al., 2020). We should attempt to reframe the situation as an opportunity for growth, for reflection, for change, and for developing resiliency.

Because the space between stimulus and response is where our growth and serendipity lie - in the long run.

Chaos theory also brings additional methods, based on quantitative approach, which gives space for analysis of the political systems' dynamic by graphic-based tools. They originate in the phase space of a dynamic system - the attractors and the fractals. The analysis can give practical accompaniments to the traditional scientific methods. More globally, the innovative aspects of the chaotic perspective show a promising scientific potential for analyzing and describing the time-based evolution of public policies and political institutions, actors, and processes.

Despite the fact, that the use of chaos theory has some advantages, but it also has some weak points, which should be admitted. Chaos theory is not very suitable for long-term forecasts; the complexity increases with the number of actors in the system. Nevertheless, the issue of the methodology for the long-term development of international relations is one of the eternal questions of political science.

The question remains open: whether it is possible to predict the development of macro-social systems, a variety of which is the system of international relations.

\section{Bibliographic References}

ALBERT, Eleanor. 2020. "Coronavirus Outbreak: What Is the World Doing to Help China?” In: Diplomat Media INC. Available online. In: https:// thediplomat.com/2020/02/coronavirus-outbreak-what-is-the-worlddoing-to-help-china/. Consultation date: 23/08/2020.

BALDWIN, Richard; WEDER DI MAURO, Beatrice (ed.). 2020. Centre for economic policy research. 2020. Economics in the time of covid-19. Available online. In: Available online. In: https://voxeu.org/article/ economics-time-covid-19-new-ebook. Consultation date: 18/11/2020.

BIGGERI, Annibale; DE BRUNA, Marchi; FUNTOWICZ, S.O; GIAMPIETRO, Mario; O'Connor, Martin Paul; RAVETZ, Jerome R; SALTELLI, Andrea; SLUIJS, Van Der J.P. 2020. "Post-normal Pandemics: Why Covid-19 requires a New Approach to Science" In: Steps Centre. Available online. In: https://steps-centre.org/blog/postnormal-pandemics-whycovid-19-requires-a-new-approach-to-science/. Consultation date: 14/06/2020. 
Natalia Vladimirovna Kovalevskaia, Iuliia Alexandrovna Fedoritenko y William Leahy

BONDARENKO, N.G; KASPARYAN, K.V; KOVALEVSKAYA, N.V; GRUNDEL, L.P; BAGRATUNI, K.Y. 2018. "The role of investments in the development of integration association of Southeast Asian nations (ASEAN)" In: International Journal of Civil Engineering and Technology. Vol. 9, No. 11, pp. 1720-1729.

BYEON, Jong Heon. 1999. "Non-Equilibrium Thermodynamic Approach to Change in Political Systems" In: Systems Research and Behavioral ScienceSyst. Res. Vol. 16, pp. 283-291.

CHENG, Vincent C.C; LAU, Susanna K.P; WOO, Patrick C.Y; YUEN, Kwok Yung. 2007. "Severe Acute Respiratory Syndrome Coronavirus as an Agent of Emerging and Reemerging Infection" In: Clin Microbiol Rev. Vol. 20, No. 4, pp. 660-694.

COMMITTEE FOR THE COORDINATION OF STATISTICAL ACTIVITIES. 2020. How COVID-19 is changing the world: a statistical perspective. Available online. In: https://openknowledge.worldbank.org/ handle/10986/33773. Consultation date: 14/06/2020.

ERMOLINA, Maria; MATVEEVSKAYA, Anna; MATYASHOVA, Daria; KOVALEVSKAYA, Natalia. 2020. "Priorities for sustainable urban development as exemplified by individual Asian countries" In: In E3S Web of Conferences. Vol. 157. EDP Sciences. Available online. In: https://doi.org/10.1051/e3sconf/202015703013. Consultation date: 14/09/2020.

GILEAD. 2020. Update on the Company's Ongoing Response To COVID-19. Available online. In: https://www.gilead.com/purpose/advancingglobal-health/covid-19. Consultation date: 14/09/2020.

GLEICK, James. 1987. Lafe's Ups and Downs. Chaos: Making a New Science. Viking. New York, USA.

GRAIS, Rebecca F; ELLIS, Hugh J; GLASS, Gregory E. 2003. "Assessing the Impact of Airline Travel on the Geographic Spread of Pandemic Influenza” In: European Journal of Epidemiology. Vol. 18, No. 11, pp. 1065-1072.

JESTER, Barbara J; UYEKI, Timothy M; JERNIGAN, Daniel B. 2020. "Fifty Years of Influenza A(H3N2) Following the Pandemic of 1968" In: Am J Public Health. Vol. 110, No. 5, pp. 669-676.

LOGUNOV, Denis Y; DOLZHIKOVA, Inna V; ZUBKOVA, Olga V; TUKHVATULLIN, Amir I; SHCHEBLYAKOV, Dmitry V; DZHARULlAEVA, Alina S; GROUSOVA, Daria A; GINTSBURG, Alexander L. 2020. "Safety and immunogenicity of an rAd26 and 
rAd5 vector-based heterologous prime-boost COVID-19 vaccine in two formulations: two open, non-randomised phase 1/2 studies from Russia" In: The Lancet. Vol. 396, No. 10255, pp 887-897.

NORRIE, John David. 2020. "Remdesivir for COVID-19: challenges of underpowered studies" En: The Lancet. Available online. In: DOI: https://doi.org/10.1016/So140-6736(20)31023-0. Consultation date: 12/03/2019.

PRIGOGINE, Ilya. 1977. Time, Structure and Fluctuations. Nobel Lecture. Available online. In: https://www.nobelprize.org/uploads/2018/o6/ prigogine-lecture.pdf. Consultation date: 12/03/2019.

PRIGOGINE, Ilya; STENGERS, Isabelle. 1986. Poryadok iz haosa. Novyj dialog cheloveka s prirodoj [Order out of chaos. A new dialogue of man with nature]. Progress. Moscow, Russia (in Russian).

SHIMADA, Ichiro; KOYAMA, Tomio. 2015. "A theory for complex system's social change: An application of a general "criticality" model" In: Interdisciplinary Description of Complex Systems. Vol. 13, No. 3, pp. 342-353.

THIRD WORLD NETWORK. 2020. "COVID-19: Global trade values fell by $3 \%$ in first quarter of 2020" In: Published in SUNS \#9120 dated 14 May 2020. Available online. In: https://twn.my/title2/wto.info/2020/ ti200518.htm. Consultation date: 14/06/2020.

TUCKETT, David; SMITH, Lenny; GIGERENZER, Gerd; JOST, Jürgen. 2020. "Transmission T-023: TUCKETT on making good decisions under uncertainty (April 27, 2020)" In: TheSanta Fe Institute. Available online. In: https://www.santafe.edu/news-center/news/transmission-t-023david-tuckett-lenny-smith-gerd-gigerenzer-and-jurgen-jost-makinggood-decisions-under-uncertainty. Consultation date: 12/09/2020.

US. -CHINA ECONOMIC AND SECURITY REVIEW COMMISSION. 2020. Cascading Economic Impacts of the COVID-19 Outbreak in China. Available online.In: https://www.uscc.gov/sites/default/files/2020-04/ Cascading_Economic_Impacts_of_the_Novel_Coronavirus_ April_21_2020.pdf. Consultation date: 14/06/2020.

VIBOUD, Cecile; SIMONSEN, Lone; FUENTES, Rodrigo; FLORES, Jose, MILLER, Mark A; CHOWELL, Gerardo. 2016. "Global Mortality Impact of the 1957-1959 Influenza Pandemic” In: J Infect Dis. Vol. 213, No. 5, pp. 738-745.

WANG, Yeming; ZHANG, Dingyu; DU, Guanhua; DU, Ronghui; ZHAO, Jianping; JIN, Yang; FU, Shouzhi; WANG, Chen. 2020. "Remdesivir 
Natalia Vladimirovna Kovalevskaia, Iuliia Alexandrovna Fedoritenko y William Leahy

384

Chaos Theory: The Case of the COVID-19 Pandemic in Wuhan, China from the perspective of international relations

in adults with severe COVID-19: a randomised, double-blind, placebocontrolled, multicentre trial" In: The Lancet. Vol. 395, No. 10236, pp. 1569-1578.

WEI, Fan; KEYUE, Xu. 2020. “Closure of all Wuhan's makeshift hospitals indicates another stage in victory against COVID-19" In: Global Times. Available online. In: https://www.globaltimes.cn/content/1182224. shtml. Consultation date: 12/09/2020.

WORLD HEALTH ORGANIZATION. 2020a. Coronavirus disease 2019 (COVID-19) Situation Report - 102. Available online. In: https:// www.who.int/docs/default-source/coronaviruse/situationreports/20200501-covid-19-sitrep.pdf?sfvrsn=742f4a18_2. Consultation date: 12/09/2020.

WORLD HEALTH ORGANIZATION. 202ob. Coronavirus disease 2019 (COVID-19) Situation Report - 41. Available online. In: https:// www.who.int/docs/default-source/coronaviruse/situationreports/20200301-sitrep-41-covid-19.pdf?sfvrsn=6768306d_2. Consultation date: 12/09/2020.

WORLD HEALTH ORGANIZATION. 2020c. Coronavirus Disease (COVID-19) Dashboard. 2020. Available online. In: https://covid19.who.int/table. Consultation date: 12/09/2020.

YUAN, Zheming; XIAO, Yi; DAI, Zhijun; HUANG, Jianjun; ZHANG, Zhenhai; CHEN, Yuan. 2020. "Modelling the effects of Wuhan's lockdown during COVID-19, China" In: Bulletin of the World Health Organization. No. 98, pp- 484-494. 

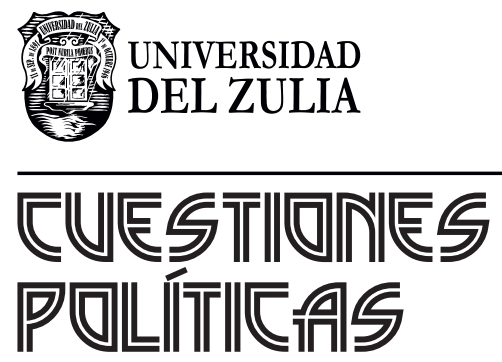

Vol.39 No 68

Esta revista fue editada en formato digital y publicada en enero de 2021, por el Fondo Editorial Serbiluz, Universidad del Zulia. Maracaibo-Venezuela 